\title{
The state of lemur conservation in south-eastern Madagascar: population and habitat assessments for diurnal and cathemeral lemurs using surveys, satellite imagery and GIS
}

\author{
Mitchell T. Irwin, Steig E. Johnson and Patricia C. Wright
}

\begin{abstract}
The unique primates of south-eastern Madagascar face threats from growing human populations. The country's extant primates already represent only a subset of the taxonomic and ecological diversity existing a few thousand years ago. To prevent further losses remaining taxa must be subjected to effective monitoring programmes that directly inform conservation efforts. We offer a necessary first step: revision of geographic ranges and quantification of habitat area and population size for diurnal and cathemeral (active during both day and night) lemurs. Recent satellite images are used to develop a forest cover geographical
\end{abstract}

information system, and censuses are used to establish range boundaries and develop estimates of population density and size. These assessments are used to identify regions and taxa at risk, and will be a useful baseline for future monitoring of habitat and populations. Precise estimates are impossible for patchily-distributed taxa (especially Hapalemur aureus, H. simus and Varecia variegata variegata); these taxa require more sophisticated modelling.

Keywords Conservation status, geographic range, GIS, lemurs, Madagascar, population densities, primates.

\section{Introduction}

The island nation of Madagascar has recently been classified as both a megadiversity country and one of 25 biodiversity hotspots, a classification reserved for regions combining high biodiversity with high levels of habitat loss and extinction risk (Myers et al., 2000). Madagascar has a diverse range of habitats, created by the interaction of an east-west rainfall gradient (most rainfall occurs in the east) and a north-south latitudinal gradient (the 1,600 km-long island spans $12-25^{\circ} \mathrm{S}$ ).

Native vegetation has been decimated throughout Madagascar since the arrival of humans on the island c. 2,000 years ago (Burney \& MacPhee, 1988; Burney, 1999). Archaeological evidence suggests that human occupation began in the south-west, followed by a gradual spread northwards and eastwards. The east may have been the last area colonized; its humidity and low altitude may have contributed to a higher risk of endemic

Mitchell T. Irwin (Corresponding author) Department of Anthropology, SBS Building, 5th Floor, Stony Brook University, Stony Brook, NY 11794-4364, USA. E-mail mirwin@ic.sunysb.edu

Steig E. Johnson Department of Anthropology, 2500 University Drive NW, University of Calgary, Calgary, AB T2N 1N4, Canada.

Patricia C. Wright Department of Anthropology and Institute for the Conservation of Tropical Environments, Stony Brook University, Stony Brook, NY 11794-4364, USA.

Received 22 February 2004. Revision requested 9 June 2004. Accepted 2 November 2004. diseases (Burney, 1999). However, once this ecoregion was inhabited, its combination of abundant timber and nutrient-poor soil (causing a low agricultural tenure time) led to rapid deforestation.

Green \& Sussman (1990) used satellite images from 1973 and 1985 and vegetation maps from 1950 to reconstruct the deforestation history of Madagascar's eastern rainforests. They found that only 3.8 million ha ( $34 \%$ of the original cover) existed in 1985, and extrapolated a deforestation rate of 111,000 ha $(1.5 \%)$ per year. At this pace, the entire loss of this ecosystem is predicted to occur by 2020.

Lemurs, Madagascar's non-human primates, are just one threatened group (17 of the 81 lemur taxa existing a few thousand years ago are extinct; Godfrey \& Jungers, 2002). As an endemic radiation of charismatic megafauna, lemurs have received international attention, although much remains to be learned about their distributions and population sizes. The most recent publications (e.g. Mittermeier et al., 1994) illustrate ranges showing little congruence with the actual extent of remaining rainforest (Green \& Sussman, 1990), and provide only general population estimates. No previous study has combined satellite imagery and censuses to generate more accurate figures (but see Sussman et al., 2003).

South-eastern Madagascar (including all eastern rainforest from its southernmost extent to the Onive/ Mangoro River in the north) contains 14 lemur taxa in nine genera and six families (Table 1). Of these, five (Hapalemur simus, Hapalemur aureus, Eulemur collaris, 
Table 1 Diurnal/cathemeral and nocturnal lemur taxa occurring in south-eastern Madagascar, with their body mass, diet and Red List status (IUCN, 2004) ${ }^{1}$.

\begin{tabular}{|c|c|c|c|c|c|c|}
\hline & Family & Taxon & Common name & $\begin{array}{l}\text { Body } \\
\text { mass }(\mathrm{kg})^{2}\end{array}$ & Diet & $\begin{array}{l}\text { Red List } \\
\text { status }^{3}\end{array}$ \\
\hline \multirow{9}{*}{$\begin{array}{l}\text { Diurnal/ } \\
\text { cathemeral }\end{array}$} & Indriidae & Propithecus diadema edwardsi & Milne-Edwards' sifaka & 6.0 & leaves, seeds, fruits & EN \\
\hline & \multirow[t]{8}{*}{ Lemuridae } & Eulemur fulvus rufus ${ }^{4}$ & Red-fronted brown lemur & 2.2 & fruit & $\mathrm{LR} / \mathrm{nt}$ \\
\hline & & Eulemur albocollaris & White-collared brown lemur & 2.2 & fruit & $\mathrm{CR}$ \\
\hline & & Eulemur collaris & Collared brown lemur & 2.5 & fruit & VU \\
\hline & & Eulemur rubriventer ${ }^{4}$ & Red-bellied lemur & 2.0 & fruit & VU \\
\hline & & Hapalemur griseus griseus ${ }^{4,5}$ & Lesser bamboo lemur & 0.7 & bamboo, fruit & $\mathrm{LR} / \mathrm{nt}$ \\
\hline & & Hapalemur aureus & Golden bamboo lemur & 1.5 & bamboo & $\mathrm{CR}$ \\
\hline & & Hapalemur simus & Greater bamboo lemur & 2.0 & bamboo & $\mathrm{CR}$ \\
\hline & & Varecia variegata variegata ${ }^{4}$ & Black-and-white ruffed lemur & 3.6 & fruit & EN \\
\hline \multirow[t]{5}{*}{ Nocturnal } & \multirow[t]{2}{*}{ Cheirogaleidae } & Cheirogaleus major & Greater dwarf lemur & 0.4 & fruit, nectar, insects & $\mathrm{LR} / \mathrm{nt}$ \\
\hline & & Microcebus rufus & Brown mouse lemur & 0.04 & fruit, insects & $\mathrm{LR} / \mathrm{nt}$ \\
\hline & Daubentoniidae & Daubentonia madagascariensis & Aye-aye & 2.6 & insect larvae, seeds & EN \\
\hline & Indriidae & Avahi laniger & Eastern woolly lemur & 1.2 & leaves & $\mathrm{LR} / \mathrm{nt}$ \\
\hline & Lepilemuridae & Lepilemur microdon & Small-toothed sportive lemur & 1.0 & leaves & $\mathrm{LR} / \mathrm{nt}$ \\
\hline
\end{tabular}

${ }^{1}$ General references: Petter et al. (1977), Tattersall (1982), Harcourt \& Thornback (1990), Mittermeier et al. (1994)

${ }^{2}$ Average of male and female body mass from Smith \& Jungers (1997)

${ }^{3}$ IUCN (2004), CBSG (2002): LR/nt, Lower Risk/near threatened; VU, Vulnerable; EN, Endangered; CR, Critically Endangered

${ }^{4}$ Taxa whose range extends beyond area considered in this study

${ }^{5} \mathrm{H}$. g. griseus is considered here to include the range of the putative taxon $\mathrm{H}$. (g.) meridionalis and other unnamed variants that may exist in the south-east (Fausser et al., 2002). As it was impossible in our surveys to distinguish between H. g. griseus and H. g. meridionalis, we cannot comment on the validity or geographic range of these taxa.

Eulemur albocollaris and Propithecus diadema edwardsi) are endemic to the region, seven (Hapalemur griseus, Eulemur rubriventer, Varecia variegata variegata, Avahi laniger, Lepilemur microdon, Cheirogaleus major and Microcebus rufus) are endemic to eastern rainforests, and only two (Eulemur fulvus rufus and Daubentonia madagascariensis) are more widely distributed. This region contains $22 \%$ of Madagascar's 64 lemur taxa, 29\% of its 48 species, $64 \%$ of its 14 genera and all of its five endemic families (taxonomy follows CBSG, 2002). There are seven protected areas in the south-east (Fig. 1 \& Table 2).

This paper aims to provide a quantitative assessment of diurnal and cathemeral (active during both day and night) lemur populations in south-eastern Madagascar. To achieve this we: (1) Use census data to delineate geographic ranges, generate population density estimates for each taxon at each site and estimate overall density for each taxon across its range. (2) Create a geographical information system (GIS) coverage representing rainforest cover, and subdivide this area based on ranges of individual taxa to quantify available habitat. (3) Combine population densities and habitat assessments to estimate the regional population size for each taxon.

Nocturnal lemurs were excluded for four reasons. Firstly, population sizes of nocturnal species as currently recognized are probably high; all are found throughout and beyond the region, are smaller-bodied, and live at higher population densities. Secondly, they are less affected by hunting (although those sleeping in tree holes may be vulnerable). Thirdly, the assumptions of line-transect surveys are harder to meet for nocturnal species (Duckworth, 1998), causing greater estimation error. Fourthly, the taxonomy of eastern nocturnal species is poorly understood; revisions of nocturnal lemur taxonomy elsewhere in Madagascar (Rasoloarison et al., 2000) found greater species richness than previously recognized. Population size estimates should therefore await revisions of taxonomy and geographic range.

\section{Methods}

\section{Population densities}

Between 1995 and 2001 we censused 20 localities throughout the south-east (Fig. 1 \& Table 3). Data was collected primarily by ourselves, but supplemented by unpublished data provided by S. Arrigo-Nelson and C. Grassi as part of an ongoing collaboration (Johnson et al., 2003). Methodology has been described elsewhere (Johnson \& Overdorff, 1999; Irwin et al., 2000, 2001) and followed previous studies (Struhsaker, 1981; Fashing \& Cords, 2000). At each site 1-4 transects were established (length $0.8-3.8 \mathrm{~km}$ ); existing trails were sometimes used but only when not affected by anthropogenic disturbance. For each lemur sighting we recorded observer-to-animal and perpendicular sighting distances (measured to the centre of the group), and group size.

Transect area was calculated using the histograminspection technique (Whitesides et al., 1988; Plumptre, 2000). Observer-animal sighting distances were placed 


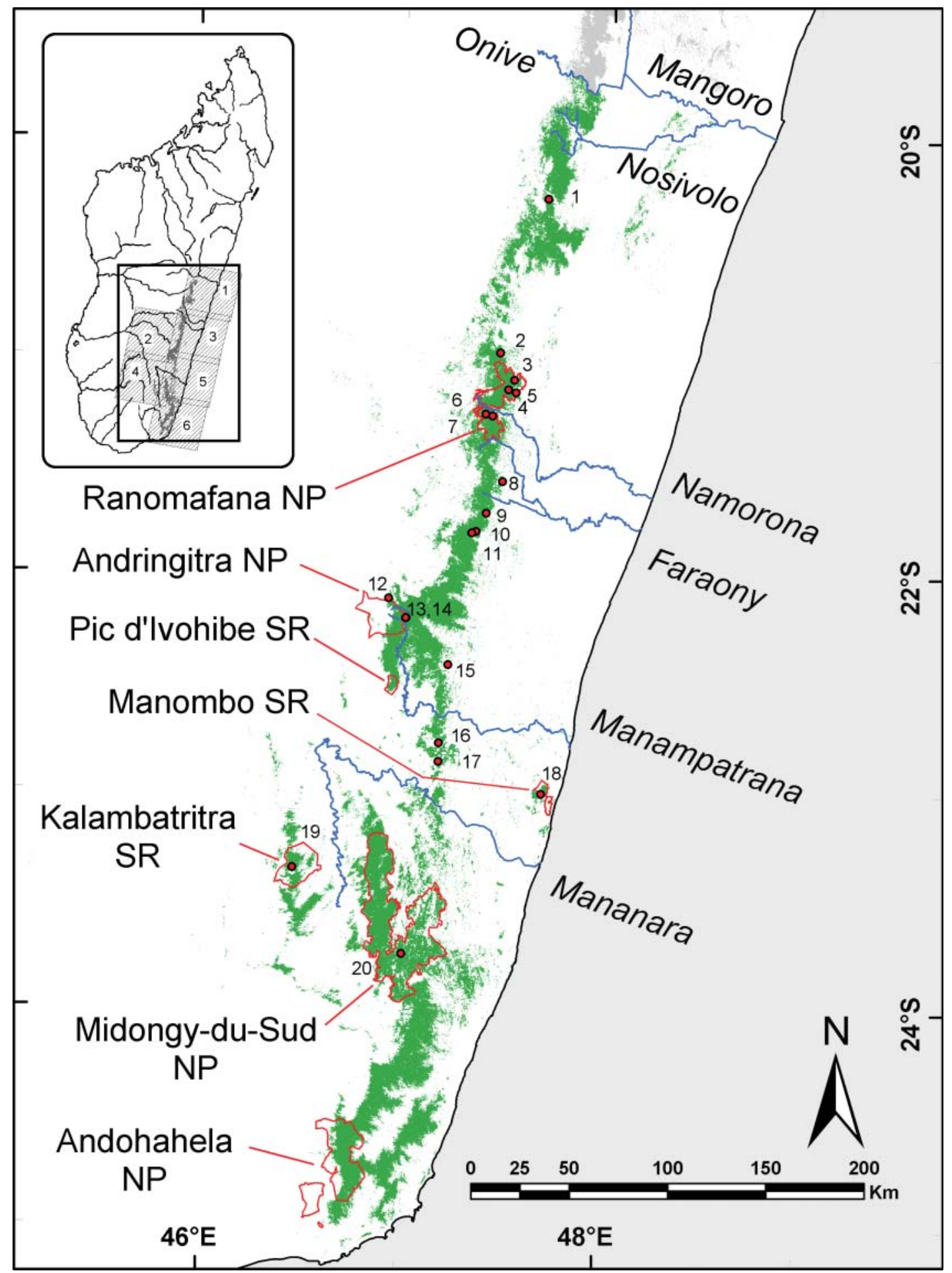

Fig. 1 Rainforest of south-eastern Madagascar (green) based on Landsat 7 satellite images for 1999-2001, with east-flowing rivers and protected areas (SR, Special Reserve; NP, National Park) including rainforest (outlined in red; data courtesy of ANGAP). Rainforest corridor extends north past study area (indicated in grey). Red dots indicate the 20 survey sites (see Table 3). Inset: position of study area within Madagascar, with extent of satellite images used in this study. Image ID numbers and acquisition dates are:

1, E1SC:L70RWRS.002:2000973352, 19/04/2000; 2, E1SC:L70RWRS.002:2000319961, 17/10/1999; 3, E1SC:L70RWRS.002:2000443464, 11/11/ 1999; 4, E1SC:L70RWRS.002:2000319964, 17/10/1999; 5, E1SC:L70RWRS.002:2001961696, 29/11/2000; 6, E1SC:L70RWRS.002:2004077212, $13 / 09 / 2001$. 
Table 2 Protected areas of south-eastern Madagascar (see Fig. 1 for locations), with date gazetted, area, approximate rainforest area, and altitudinal range ${ }^{1}$.

\begin{tabular}{llccc}
\hline Name & Date gazetted & Area (ha) & Approximate rainforest area (ha) & Altitudinal range (m) \\
\hline Ranomafana National Park & 1991 & 43,500 & 43,500 & $400-1,534$ \\
Andringitra National Park & $1927^{2}$ & 31,160 & 15,000 & $650-2,658$ \\
Pic d'Ivohibe Special Reserve & 1964 & 3,453 & 3,453 & $775-2,060$ \\
Kalambatritra Special Reserve & 1959 & 28,250 & $13,060^{3}$ & $740-1,680$ \\
Manombo Special Reserve & 1962 & 5,320 & $2,660^{4}$ & $0-137$ \\
Midongy du Sud National Park & 1997 & 197,900 & 197,900 & $850-1,357$ \\
Andohahela National Park & $1939^{5}$ & 76,020 & $63,100^{6}$ & $90-1,972$ \\
Totals & & 385,603 & 338,673 & \\
\hline
\end{tabular}

${ }^{1}$ From Nicoll \& Langrand (1989), Ramarokoto et al. (1999)

${ }^{2}$ Upgraded from Réserve Naturelle Intégrale (Integral Natural Reserve) to National Park in 1998

${ }^{3}$ From Intercoopération Suisse \& Marie ERTA (1999)

${ }^{4}$ Approximately half of Manombo Special Reserve remains forested (Steig E. Johnson, pers. obs.; J. Ratsimbazafy, pers. comm.)

${ }^{5}$ Upgraded from Réserve Naturelle Intégrale to National Park in 1997

${ }^{6}$ Parcel 1 (rainforest) only; Parcels 2 and 3 (dry and transitional forest) excluded

into $5 \mathrm{~m}$ categories, and the boundary at which observation frequencies dropped to $\leq 50 \%$ of the previous interval was the 'fall-off distance'. We used observeranimal distance because perpendicular distances were not available for some sites, and, although the method was formulated for perpendicular distances, it can be applied to observer-animal distances (Fashing \& Cords, 2000). Considering all species for which both types of data were available, and for which observations exceeded 30 sightings, density estimates differed by $<15 \%(\mathrm{n}=3)$.

Effective distance $\mathrm{E}$ was calculated as:

$$
E=\frac{N_{t}}{N_{f}} F D
$$

where $N_{t}$ is the number of sightings, $N_{f}$ is the number of sightings at less than the fall-off distance, and $F D$ is the fall-off distance (Whitesides et al., 1988). Effective distance was calculated individually for each species, except for the brown lemur group, within which sightings were pooled.

Population density $D$ was calculated as:

$$
D=\frac{I}{2 E L_{t}}
$$

where $I=$ numbers of individuals observed, $E=$ effective distance, and $L_{t}=$ total transect length (transect length * number of repetitions).

\section{Geographic ranges}

In assessing geographic ranges we considered the most recent published data as null hypotheses to be tested by our data. Our survey locations were distributed throughout the study area, except for the extreme south; to confirm species incidence in this region we relied on O'Connor et al. (1986) and Feistner \& Schmid (1999).
Because of the close spacing of survey sites, we believe our data provide a fine-grained test of range limits.

\section{Habitat assessment}

We analyzed six Landsat 7 multispectral satellite images acquired between 1999 and 2001 (USGS, 2004). Images were chosen to be in as narrow a time window as possible whilst minimizing cloud cover. Using Erdas Imagine (Leica Geosystems, Atlanta, USA) we performed a 2-class supervised classification to identify forested areas. For each image, a spectral signature was acquired from a ground-truthed rainforest area, and this signature (incorporating visible, infrared, and near-infrared wavelengths), was used to classify the image into forest and non-forest. The resulting images were imported into ArcGIS 8.0 (ESRI, Redlands, USA) and smoothed using majority neighbourhood statistics. All fragments $<1$ ha were removed.

The six images were then examined to judge the amount of offset between them in areas of overlap (due to small georectification errors). Merging offset images creates a ghosting effect, whereby forest in mosaic habitats can be counted twice. When offset was found, images were manually shifted to match one another (accuracy in area calculations was given priority over small geographic shifts). The images were then joined to create a single image; in overlap areas, pixels were judged to be forest if one or more of the contributing images showed forest at that location (this additive approach was critical in one overlap area, where images had cloud cover at different locations). The resulting image was then converted to a polygon coverage and clipped to correspond to the observed geographic ranges of individual lemur taxa, thus producing an 'available habitat' layer for each taxon.

To investigate the forest's altitudinal distribution, we used a GTOPO30 digital elevation model, (USGS, 2003) 


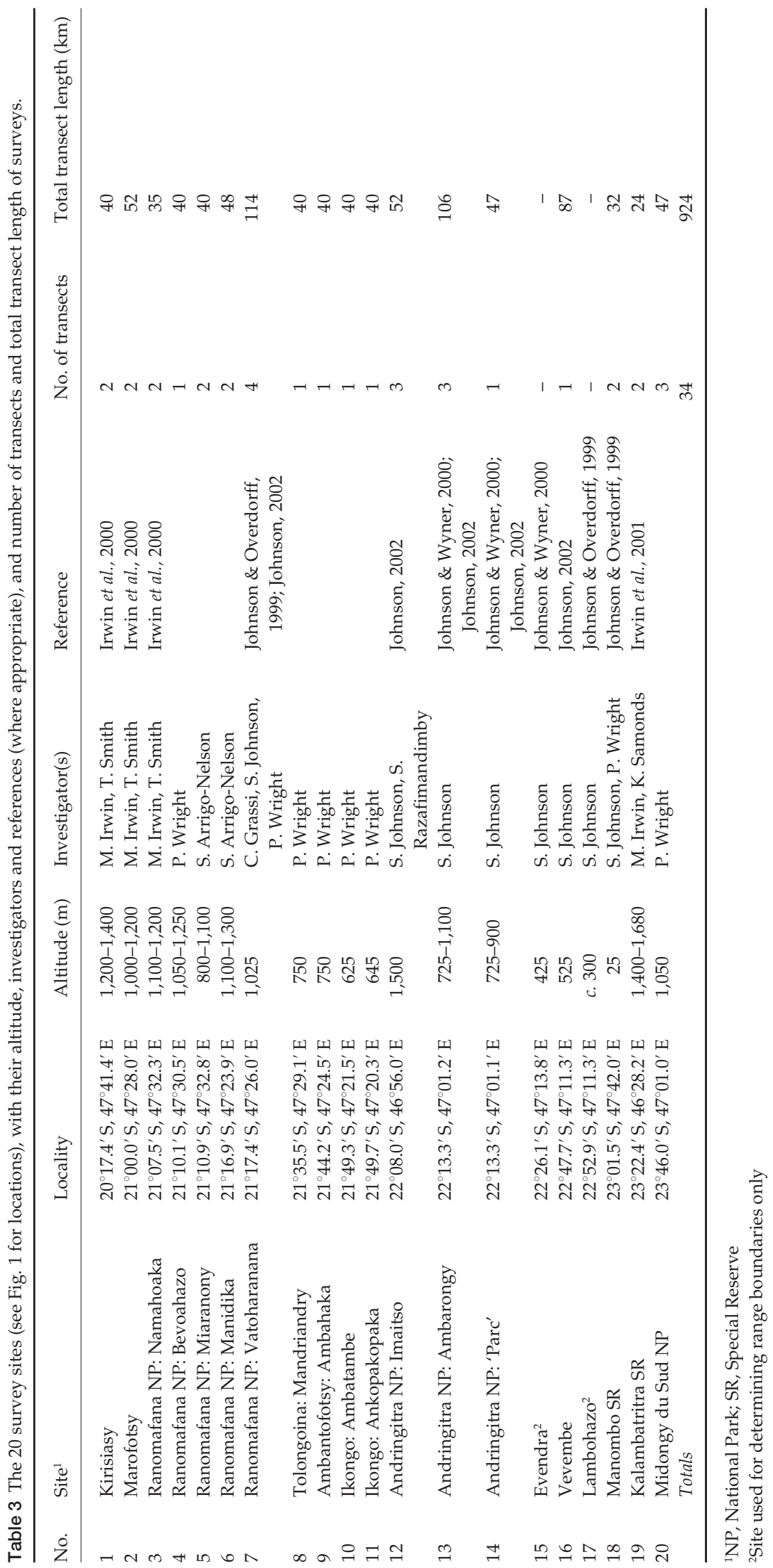


The model was classified into $200 \mathrm{~m}$ intervals and intersected with the forest coverage, dividing the forest by altitudinal category.

\section{Population estimates}

We estimated the regional population size of each taxon by multiplying estimated habitat area $\left(\mathrm{km}^{2}\right)$ by average population density (individuals $\mathrm{km}^{-2}$ ). Population density values were the arithmetic means of densities at all sites within the taxon's range, including sites where they are known to exist but were not detected during censuses (in these cases, zero values were used). We also calculated estimates using only habitat within protected areas.

\section{Sources of error}

Spatial heterogeneity in population density

Population density was estimated using the mean of densities at different sites; we did not model spatial heterogeneity. This undoubtedly leads to error, as lemur occurrence and densities vary non-randomly with habitat type, disturbance and altitude (Ganzhorn, 1995; Sterling \& Ramaroson, 1996; Ganzhorn et al., 1997a; Goodman \& Rasolonandrasana, 2001). However, the sampling effort necessary to adequately model this heterogeneity is beyond the scope of this study. As our survey sites are evenly distributed throughout the south-east (geographically and by altitude), and include protected and unprotected forests, we believe that our estimates are reasonable reflections of overall densities. Estimates will be least accurate for patchily-distributed taxa.

\section{Interspecific differences in detection}

Taxa differ in habitat use, locomotion, group size, anti-predator strategies and response to observers; these factors cause differences in detectability. Our methods underestimate the population size of less easily detected taxa.

\section{Misclassification of forest in satellite imagery}

We believe that misclassification was rare in our analysis. Ground-truthing upheld the sharp distinction between forest and non-forest visible even in raw images. However, it is possible that our forest coverage contains some non-habitat areas (e.g. degraded forest, plantations), leading to overestimation. Further groundtruthing would be necessary to determine whether these areas can be reliably distinguished.

\section{Under-representation of forest due to cloud cover}

Although we attempted to avoid cloud cover in the images certain forest areas were obscured, and there are no reliable techniques of countering this shortcoming. We considered cloud-covered areas as non-forest; underestimation of habitat area due to clouds was estimated to be $<5 \%$, and is primarily found between the Mananara and Manampatrana Rivers.

\section{Results}

\section{Habitat assessment}

We found that $11,433 \mathrm{~km}^{2}$ of rainforest remains in the south-east (Fig. 1), of which $3,386 \mathrm{~km}^{2}(29.6 \%)$ is within protected areas. Visual inspection reveals that the north-south corridor has become discontinuous in two locations. The first is just north of Ranomafana (approximately $21^{\circ} \mathrm{S}$ ); the images used had no cloud cover in this region. The second location is between the Manampatrana and Mananara Rivers (continuing south of the Mananara). The images had significant cloud cover in this area, making finer quantification of deforestation difficult.

Remaining rainforest is concentrated at mid-altitudes (70\% is between 600 and 1,400 m), straddling the escarpment dividing the eastern lowlands from the central plateau (Fig. 2). Lowland rainforest (<500-600 m; Ganzhorn et al., 1997b) appears to be rare, especially relative to the north-east (Green \& Sussman, 1990). This includes the unique coastal forest, which has been reduced to disconnected fragments (Ganzhorn et al., 2001).

\section{Lemur populations}

Geographic ranges of lemur taxa as determined by this study are shown in Fig. 3; Table 4 summarizes differences between previous accounts of range boundaries and those found by this study. A revised incidence of lemurs in south-eastern protected areas is shown in Table 5 .

Habitat area and population size estimates are summarized in Table 6. We did not calculate density for $H$. simus (due to low sample size), or estimate population size for three patchily-distributed species (H. aureus, $H$. simus and $V$. variegata variegata).

\section{Discussion}

South-eastern Madagascar still contains viable forest habitat, but continual monitoring and intervention will be necessary for preservation. Specifically, two major recommendations arise from this study. Firstly, special attention should be paid to the two regions in which the forest corridor has become discontinuous. These discontinuities will pose barriers to gene flow and reduce effective population size of subdivided populations. 


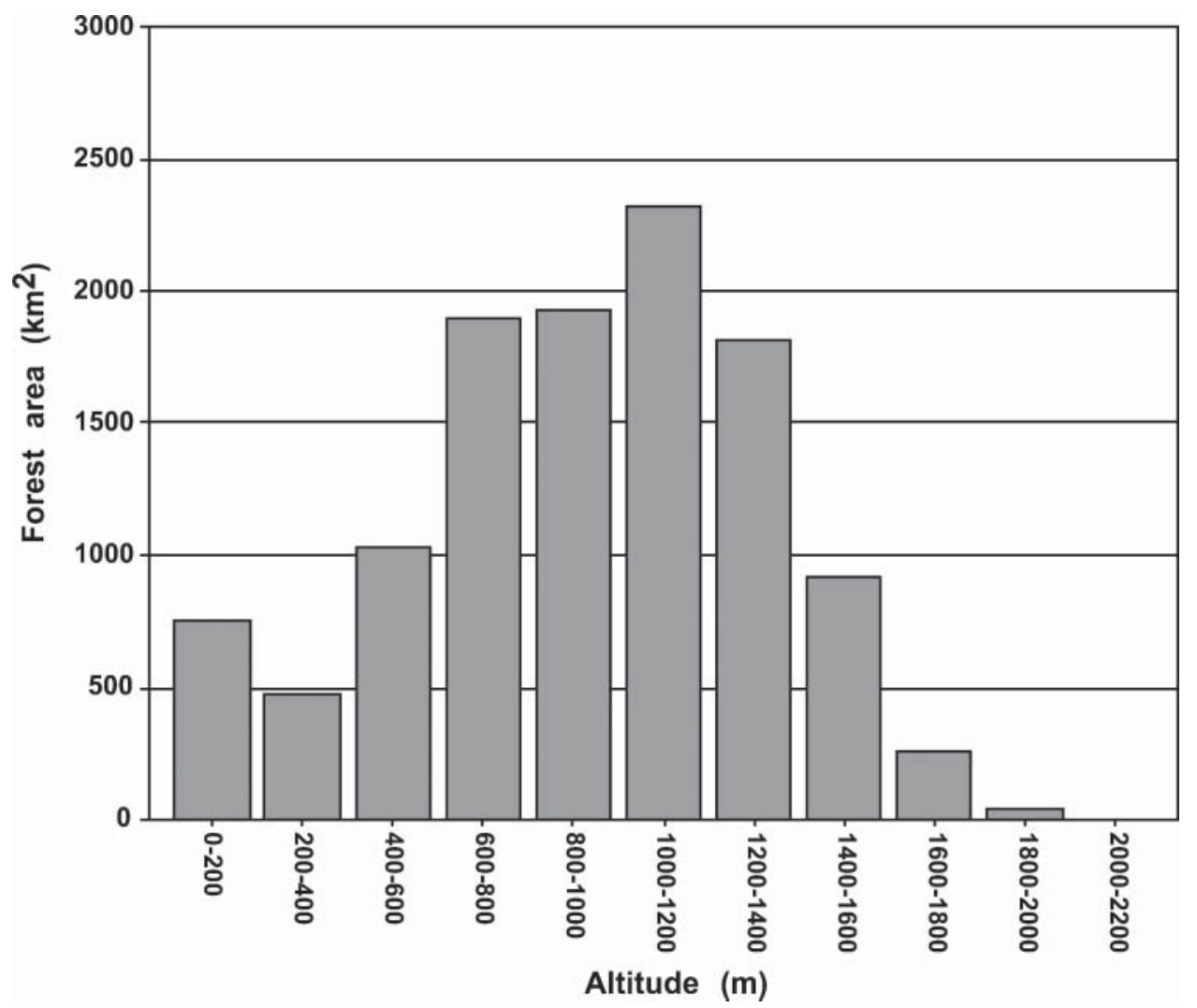

Fig. 2 Areas of rainforest in south-eastern Madagascar by altitude.

Secondly, special attention should be paid to both lowaltitude and high-altitude forests, as examples of both are rare and isolated. Low-altitude forests exist as small fragments, whereas high-altitude forests are part of the corridor but patchily-distributed (i.e. connected by lower-altitude forests). This combination of scarcity and fragmentation indicates disproportionate extinction risk for taxa restricted to these forest types; i.e. local extinctions due to low effective population size, and lack of recolonization due to isolation. Efforts should be made to investigate the biodiversity at risk, and extend habitat protection to include more lowland and montane areas.

Our surveys provided small but important clarifications of range boundaries for the diurnal and cathemeral lemur species of south-eastern Madagascar, and revealed the large extent of the E. f. rufus $x$ E. albocollaris hybrid zone in and around Andringitra (Johnson \& Wyner, 2000; Johnson, 2002; Wyner et al., 2002). We were able to estimate regional population size for seven of 10 taxa considered. These estimates reveal a wide range of population sizes (from $<8,000$ to almost 100,000 individuals) and indicate clear conservation priorities. Similarly, although the overall proportion of protected habitat is relatively high, species vary widely in the size of their protected population.
E. albocollaris appears to be the most seriously threatened, with by far the smallest overall and protected populations. Its range was the area most affected by cloud cover; however, even assuming a generous underestimate of area (e.g. 25\%), this species is still more threatened than other species. P. d. edwardsi also has a small protected population, due to low density and the fact that the northern part of the study area, where they are found, has less protected area than the south. E. rubriventer has similarly low numbers but is well represented in protected areas in the north-east. Other taxa are in less immediate danger, having large ranges and/or good representation in protected areas. However, all taxa should be monitored both within and outside protected areas.

Various characteristics of particular taxa affect the reliability of our results, and precluded estimations for three taxa. Problems with estimation always involved patchy or incomplete presence within the geographic range, arising from the following processes: true ecological patchiness due to habitat requirements, altitudinal restrictions, and hunting. Specific cases are as follows:

Eulemur rubriventer is apparently confined to mediumand high-altitude forests (Mittermeier et al., 1994), but we were unable to test this assertion because lowland 

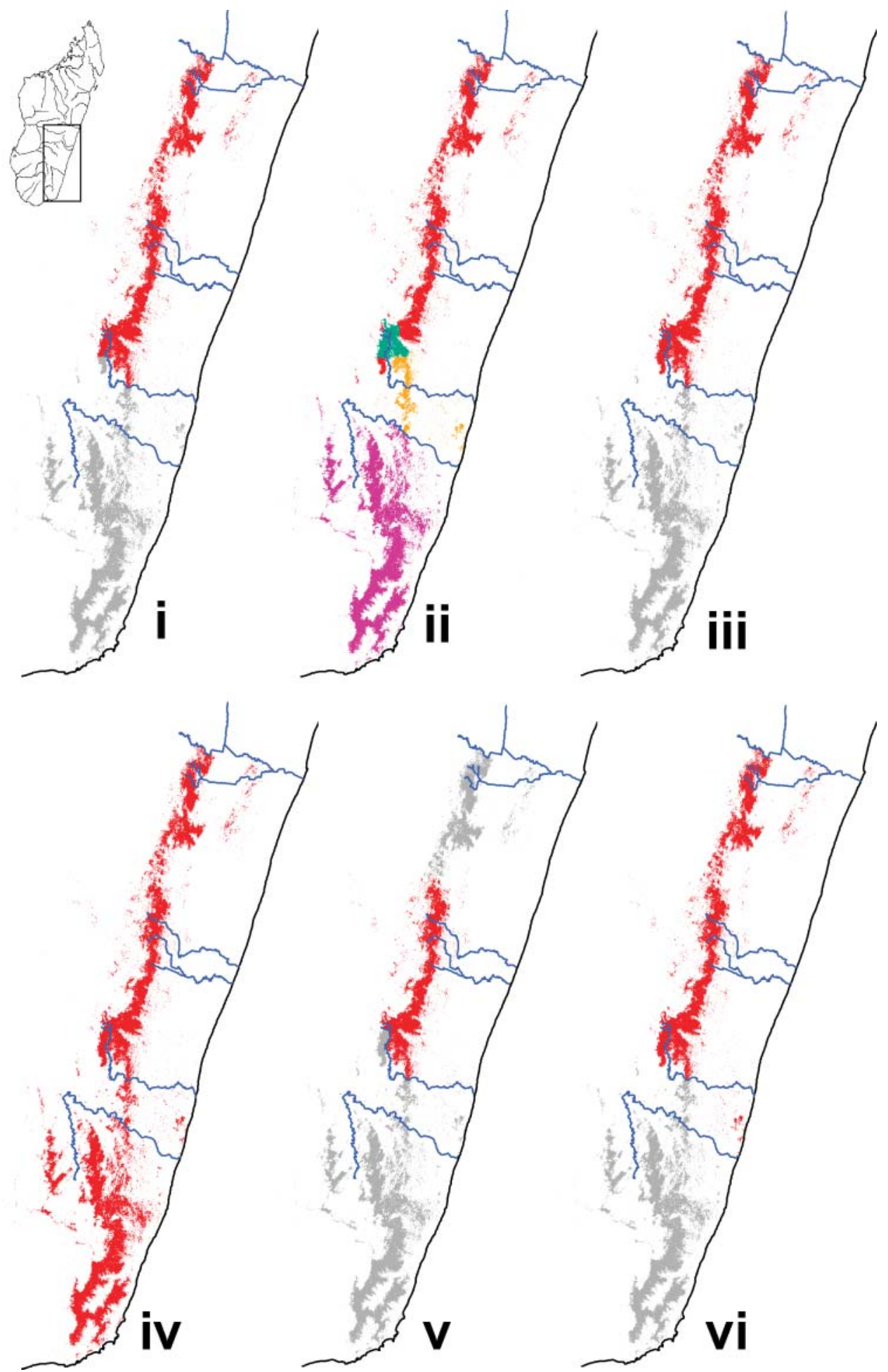

Fig. 3 Ranges of individual lemur taxa discussed in text: i, Propithecus diadema edwardsi; ii, Eulemur fulvus rufus (red), Eulemur fulvus rufus $\mathrm{x}$ Eulemur albocollaris (green), Eulemur albocollaris (yellow), Eulemur collaris (purple); iii, Eulemur rubriventer; iv, Hapalemur griseus griseus; $\mathrm{v}$, Hapalemur aureus and Hapalemur simus (same range); vi, Varecia variegata variegata. 

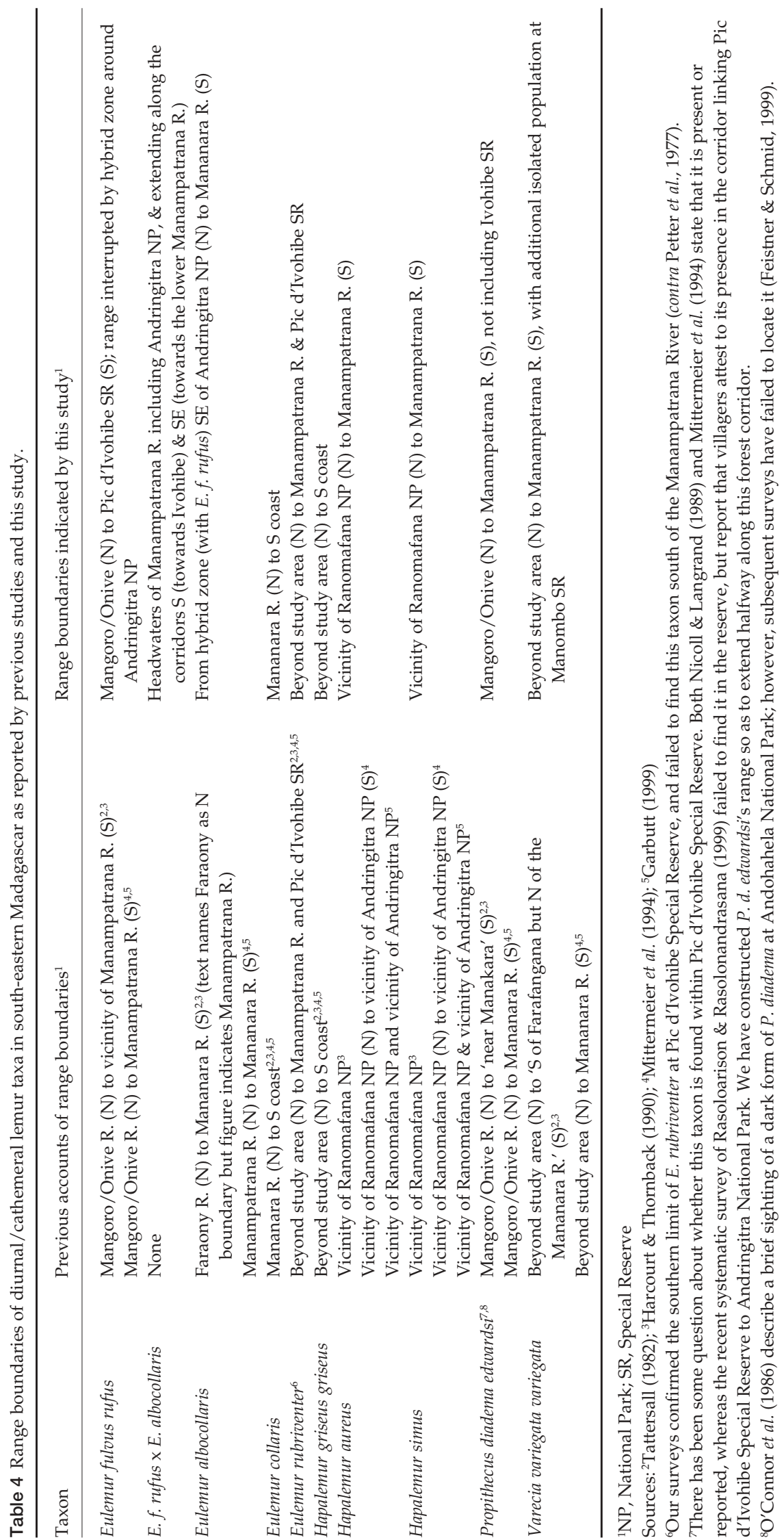


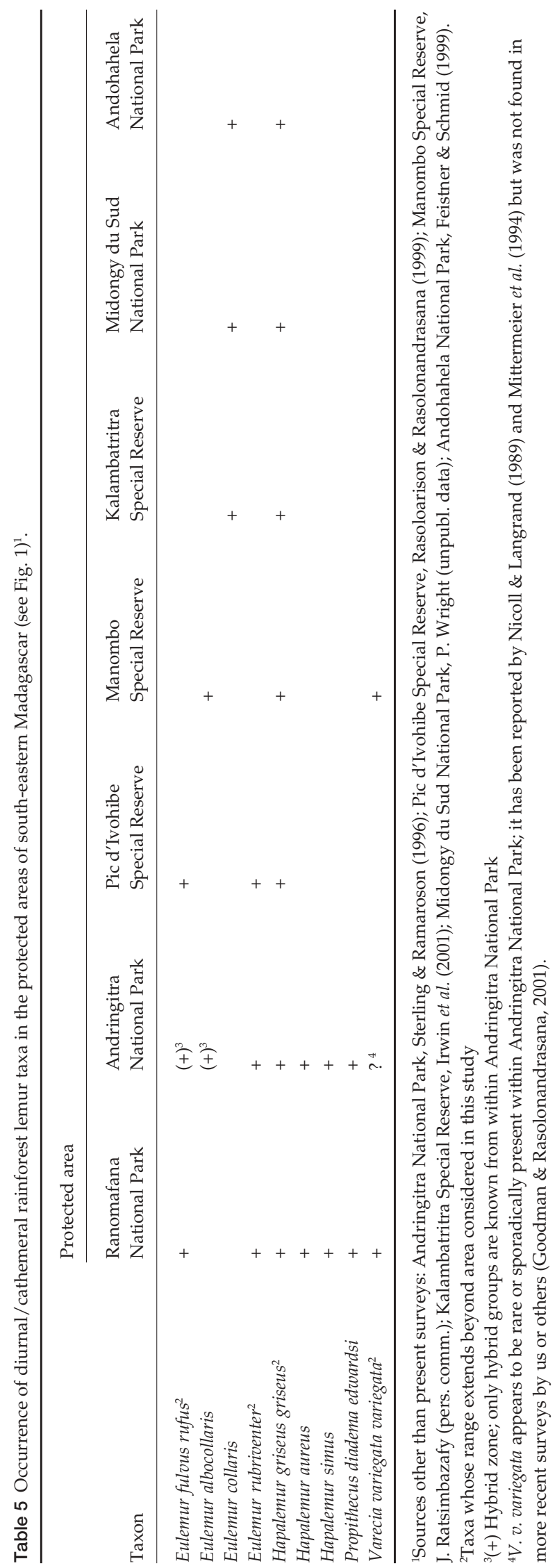




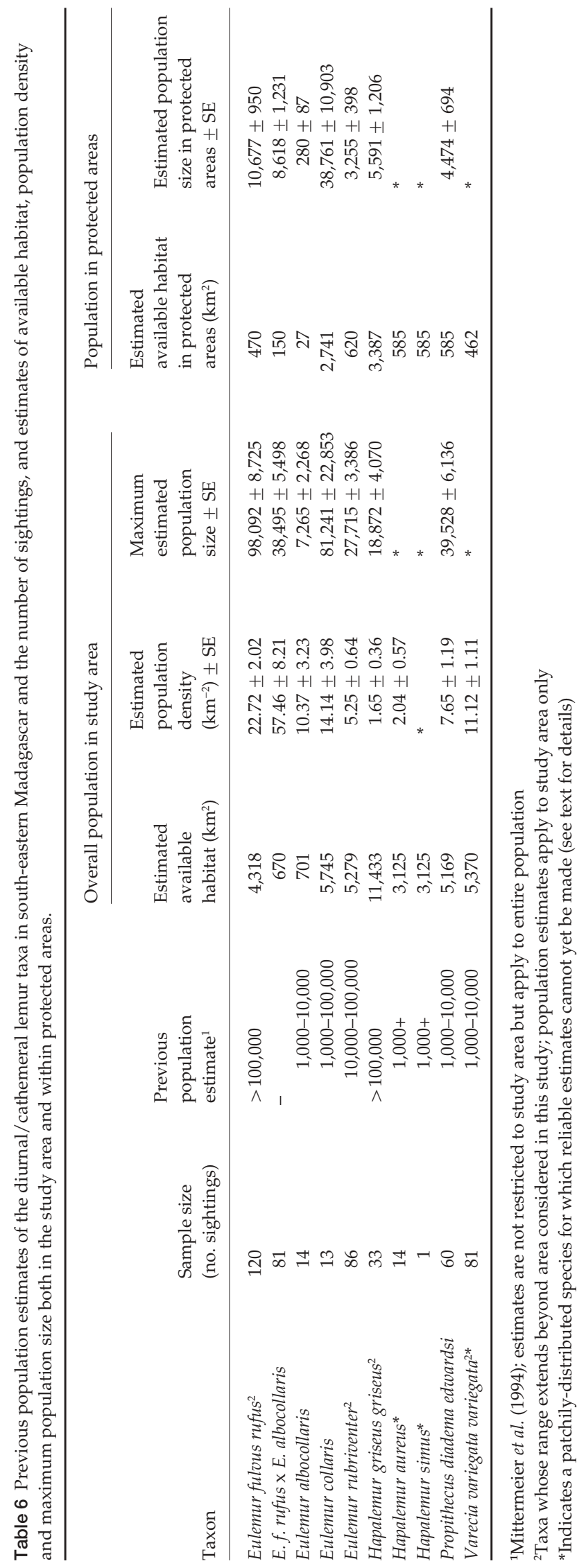


rainforests are extremely rare in the south-east, and surveys were thus concentrated in medium to highaltitude forests. This does mean, however, that our population size estimate is unlikely to be greatly inflated due to altitudinal preference.

Hapalemur aureus was discovered in 1986 at Ranomafana (Meier et al., 1987; Wright et al., 1987), and in 1993 at Andringitra (Sterling \& Ramaroson, 1996). Recent surveys in the corridor between these parks found H. aureus at four of eight sites (Goodman et al., 2001). We are aware of no sightings north of Ranomafana or south of Andringitra, but tentatively place its southern limit at the Manampatrana River, the closest major barrier. As this species is patchily-distributed due to habitat requirements (it is a bamboo specialist), simple estimation of population size is impossible. The population size if uniformly distributed would be 5,916 individuals, but we believe that actual population size is much smaller, perhaps $25 \%$ of this estimate. Further surveys are necessary to understand the microhabitat preferences of this Critically Endangered species. If these could be quantified, and preferred habitats could be detected in satellite images, incidence models could be developed to generate more accurate estimates.

Hapalemur simus was first described in 1870 , but during the 1980s was almost unknown from contemporary accounts and thought to be extinct. Museum records indicate a large range in historic times throughout most of the eastern forests, and subfossil remains from northwestern and central Madagascar (beyond the rainforest's present extent) suggest a wider distribution in previous centuries (Tattersall, 1982; Godfrey et al., 2004). Presently, $H$. simus occurs only within Ranomafana, Andringitra, corridor and isolated forests between and to the east of these localities, and one locality (Evendra) south-east of Andringitra but north of the Manampatrana River. Goodman et al. (2001) found H. simus at only one of eight sites in the Ranomafana-Andringitra corridor. We therefore tentatively present a geographic range between the Manampatrana River in the south, and Ranomafana in the north. As this species is furtive and restricted by microhabitat, and was rarely detected during surveys, we cannot reliably estimate population size. Given its observed range and extreme patchiness, we believe $H$. simus to be substantially less abundant than H. aureus.

Propithecus diadema edwardsi is patchily distributed due to hunting pressure. Evidence from outside protected areas indicates that this taxon is heavily hunted throughout much of its range (especially north of Ranomafana; Irwin et al., 2000; Lehman \& Wright, 2000). Our estimate is probably too large, but without more detailed information the degree of overestimation is unclear. We conservatively estimate population size to be approximately half of the calculated value, or 20,000 individuals.
Varecia variegata variegata is patchily distributed, both according to previous accounts and this study. Three factors contribute to this patchiness. Firstly, this largebodied frugivore is dependent on primary rainforest and is absent from areas with even mild disturbance (White et al., 1995). Secondly, V. v. variegata is confined to lowand mid-altitude forests ( $<1,200 \mathrm{~m}$; Mittermeier et al., 1994). This is particularly critical in south-eastern Madagascar, where low-altitude forest is rare; $25 \%$ of forest is above 1,200 $\mathrm{m}$ (Fig. 2). Thirdly, V. v. variegata is especially susceptible to hunting due to its large size and loud alarm calls. This species' complex, patchy distribution precludes simple estimation of population size. Further models incorporating altitude, habitat quality and hunting should be applied to develop more accurate estimates for this Endangered species.

Lemurs in south-eastern Madagascar face four main types of threat: (1) habitat loss, (2) fragmentation, (3) habitat disturbance, and (4) hunting. Forest continues to be lost throughout the south-east, mostly due to smallscale shifting agriculture. The practice of tavy, cutting forest and then burning the dried vegetation, is used to create arable land (Gade, 1996). After a brief period of cultivation (usually $<10$ years), the land becomes unusable and new plots are cleared.

Because deforestation usually occurs at small spatial scales, remaining forest becomes increasingly fragmented. Living in fragments poses several dangers to forest-adapted species (Turner, 1996). Small, isolated populations face extinction due to genetic, demographic and/or environmental stochasticity (Lande, 1998), and reduction in migration means that local extinctions may not be easily reversed by recolonization. In addition, edge effects change habitat suitability (Murcia, 1995) through abiotic effects (e.g. wind and sun penetration), consequent biological effects, and anthropogenic effects such as hunting and disturbance.

Human populations also affect plant and animal communities through resource extraction. The use of trees and other forest products for food, construction or textile manufacture affects vegetative structure and species composition, thus affecting lemur populations. One severe example of this has been observed in the northern part of the study region. The bark of Syzygium trees (Myrtaceae) is used as an additive in rum-making; bark-stripping causes high mortality, possibly affecting lemur populations by reducing food availability (Irwin \& Ravelomanantsoa, 2004).

Hunting displays great geographic and cultural variability, but appears capable of locally decimating lemur populations (Irwin et al., 2000; Goodman \& Raselimanana, 2003). Two types of hunting are known: projectile hunting (spears, slings, blowguns and, rarely, firearms) and trapping. Trapping usually involves snares set along horizontal supports in deforested strips, and is 
thought to mostly target Eulemur, Varecia and Hapalemur species, which move quadrupedally across the supports.

Extensive, quantitative monitoring programmes will be essential to the survival of these unique primates. We offer a necessary first step: revision of species ranges and quantitative assessments of habitat area and population size. These assessments are used to identify regions and taxa at risk, and can be used as a baseline for future monitoring of forest cover and population densities. However, methodologies should be refined for patchily-distributed taxa (especially $H$. aureus, $H$. simus and $V$. v. variegata), which require more sophisticated incidence models. We therefore recommend: (1) continued monitoring of forest cover changes through remote sensing, and (2) accumulating survey data at finer scales and across broader habitat gradients (location, elevation and disturbance level). The data generated through these approaches will be indispensable in future efforts to identify and manage lemur populations at risk of extinction.

\section{Acknowledgements}

We thank the Government of the Democratic Republic of Madagascar, the Association Nationale pour la Gestion des Aires Protégées, the Direction des Eaux et Forêts, and CAFF/CORE (Commission Tripartite) for permission to conduct research. Thanks to Benjamin Andriamihaja and MICET/ICTE for research facilitation. Funding was provided by Margot Marsh Biodiversity Foundation, Primate Conservation, Inc., University of Texas at Austin, Wenner-Gren Foundation for Anthropological Research (6414), National Science Foundation (BCS9910257), IIE Fulbright, United Nations Foundation, and UNESCO. We thank our students (Vaniah Andrianjaka, Tantely Andrianjazalahatra and Jean-Luc Raharison), and research assistants (François Monja, Emile Rajeriarison, Jean-Claude Rakotoniaiana, Georges Rakotonirina, Joseph Rakotozafy II, Richard Randriamampionona, Jean-Francois Randriatsilanisoa, Loret Rasabo, François Ratalata, Raymond Ratsimbazafy, Sylvain Razafimandimby, Berthin Razafy-Jerome, Justin Solo and Pierre Talata). We are greatly appreciative for unpublished data supplied by Summer Arrigo-Nelson and Christina Grassi. Additional thanks to Karen Samonds, Avri Beard, Rickie van Berkum, David Burney, Lauren Donovan, Jukka Jernvall, Rachel Kitko, Bill Konstant, Stephen Nash, Deborah Overdorff, Aimée Razafiarimalala, Noel Rowe, Tanya Smith, Elizabeth Stone and Rebecca Stumpf.

\section{References}

Burney, D.A. (1999) Rates, patterns, and processes of landscape transformation and extinction in Madagascar. In Extinctions in Near Time: Causes, Contexts, and Consequences (ed. R.D.E. MacPhee), pp. 145-164. Plenum/Kluwer, New York, USA.
Burney, D.A. \& MacPhee, R.D.E. (1988) Mysterious island: what killed Madagascar's large native animals? Natural History, 97, 46-55.

CBSG (Conservation Biology Specialist Group) (2002) L'Evaluation et Plans de Gestion pour la conservation (CAMP) de la faune de Madagascar: Lémuriens, autres mammiferes, reptiles et amphibiens, poisons d'eau douce et evaluation de la viabilité des populations et des habitat de Hypogeomys antimena (Vositse). Conservation Biology Specialist Group, Apple Valley, USA.

Duckworth, J.W. (1998) The difficulty of estimating population densities of nocturnal forest mammals from transect counts of animals. Journal of Zoology (London), 246, 466-468.

Fashing, P.J. \& Cords, M. (2000) Diurnal primate densities and biomass in the Kakamega forest: an evaluation of census methods and a comparison with other forests. American Journal of Primatology, 50, 139-152.

Fausser, J.-L., Prosper, P., Donati, G., Ramanamanjato, B. \& Rumpler, Y. (2002) Phylogenetic relationships between Hapalemur species and subspecies based on mitochondrial DNA sequences. BMC Evolutionary Biology, 2, 4.

Feistner, A.T.C. \& Schmid, J. (1999) Lemurs of the Réserve Naturelle Intégrale d'Andohahela, Madagascar. In A Floral and Faunal Inventory of the Réserve Naturelle Intégrale d'Andohahela, Madagascar: With Reference to Elevational Variation (ed. S.M. Goodman), pp. 269-283. Fieldiana Zoology, n.s. 94. Field Museum of Natural History, Chicago, USA.

Gade, D. (1996) Deforestation and its effects in highland Madagascar. Mountain Research and Development, 16, 101-116.

Ganzhorn, J.U. (1995) Low-level forest disturbance effects on primary production, leaf chemistry, and lemur populations. Ecology, 76, 2084-2096.

Ganzhorn, J.U., Lowry II, P.P., Schatz, G.E. \& Sommer, S. (2001) The biodiversity of Madagascar: one of the world's hottest hotspots on its way out. Oryx, 35, 346-348.

Ganzhorn, J.U., Malcomber, S., Andrinantoanina, O. \& Goodman, S.M. (1997a) Habitat characteristics and lemur species richness in Madagascar. Biotropica, 29, 331-343.

Ganzhorn, J.U., Rakotosamimanana, B., Hannah, L., Hough, J., Iyer, L., Olivieri, S., Rajaobelina, S., Rodstrom, C. \& Tilkin, G. (1997b) Priorities for biodiversity conservation in Madagascar. Primate Report (Special Issue), 48-1, 1-81.

Garbutt, N. (1999) Mammals of Madagascar. Yale University Press, New Haven, USA.

Godfrey, L.R. \& Jungers, W.L. (2002) Quaternary fossil lemurs. In The Primate Fossil Record (ed. W. Hartwig), pp. 97-122. Cambridge University Press, Cambridge, UK.

Godfrey, L.R., Simons, E.L., Jungers, W.L., DeBlieux, D.D. \& Chatrath, P.S. (2004) New discovery of subfossil Hapalemur simus, the greater bamboo lemur, in western Madagascar. Lemur News, 9, 9-11.

Goodman, S.M. \& Raselimanana, A. (2003) Hunting of wild animals by Sakalava of the Menabe region: a field report from Kirindy-Mite. Lemur News, 8, 4-6.

Goodman, S.M. \& Rasolonandrasana, B.P.N. (2001) Elevational zonation of birds, insectivores, rodents and primates on the slopes of the Andringitra Massif, Madagascar. Journal of Natural History, 35, 285-305.

Goodman, S.M., Razafindratsita, V., Schütz, H. \& Ratsimbazafy, R. (2001) Les Lémuriens. In Inventaire Biologique du Parc National de Ranomafana et du couloir forestier qui la relie au Parc National d'Andringitra (eds S.M. Goodman \& V.R. Razafindratsita), pp. 231-243. CIDST, Antananarivo, Madagascar.

Green, G.M. \& Sussman, R.W. (1990) Deforestation history of the eastern rain forests of Madagascar from satellite images. Science, 248, 212-215. 
Harcourt, C. \& Thornback, J. (1990) Lemurs of Madagascar and the Comoros: The IUCN Red Data Book. IUCN, Gland, Switzerland

Intercoopération Suisse (Organisation Suisse pour le Développement et la Coopération) \& Marie ERTA (Etude et Réalization de Travaux d'Amenagement) (1999) Rapport des Etudes Physico-bio-ecologiques de la Réserve Spéciale de Kalambatritra. Unpublished Report to ANGAP, Antananarivo, Madagascar.

Irwin, M.T. \& Ravelomanantsoa, H.V. (2004) Illegal rum production threatens health of lemur populations at Tsinjoarivo, eastern central Madagascar: brief report and request for information. Lemur News, 9, 16-17.

Irwin, M.T., Samonds, K.E. \& Raharison, J.-L. (2001) A biological inventory of the lemur community of Réserve Spéciale de Kalambatritra, South-Central Madagascar. Lemur News, 6, 24-28.

Irwin, M.T., Smith, T.M. \& Wright, P.C. (2000) Census of three eastern rainforest sites north of Ranomafana National Park: preliminary results and implications for lemur conservation. Lemur News, 5, 20-22.

IUCN (2004) 2004 IUCN Red List of Threatened Species. IUCN Gland, Switzerland [http:/ / www.redlist.org, accessed 23 November 2004].

Johnson, S.E. (2002) Ecology and speciation in brown lemurs: white-collared lemurs (Eulemur albocollaris) and hybrids (Eulemur albocollaris x Eulemur fulvus rufus) in southeastern Madagascar. PhD thesis, University of Texas at Austin, Austin, USA.

Johnson, S.E., Irwin, M.T., Wright, P.C., Arrigo-Nelson, S.J., Grassi, C., Samonds, K.E. \& Smith, T.M. (2003) Natural and anthropogenic influences on lemur population structure in southeastern Madagascar. American Journal of Physical Anthropology, 120(S36),123.

Johnson, S.E. \& Overdorff, D.J. (1999) A census of brown lemurs (Eulemur fulvus sspp.) in southeastern Madagascar: methods-testing and conservation implications. American Journal of Primatology, 47, 51-60.

Johnson, S.E. \& Wyner, Y. (2000) Notes on the biogeography of Eulemur fulvus albocollaris. Lemur News, 5, 25-28.

Lande, R. (1998) Anthropogenic, ecological and genetic factors in extinction and conservation. Research in Population Ecology, 40, 259-269.

Lehman, S.M. \& Wright, P.C. (2000) Preliminary study of the conservation status of lemur communities in the Betsakafandrika region of eastern Madagascar. Lemur News, 5, 23-25.

Meier, B., Albignac, R., Peyriéras, A., Rumpler, Y. \& Wright, P. (1987) A new species of Hapalemur (Primates) from south-east Madagascar. Folia Primatologica, 48, 211-215.

Mittermeier, R.A., Tattersall, I., Konstant, W.R., Meyers, D.M. \& Mast, R.B. (1994) Lemurs of Madagascar. Conservation International, Washington, DC, USA

Murcia, C. (1995) Edge effects in fragmented forests: implications for conservation. Trends in Ecology and Evolution, $10,58-62$.

Myers, N., Mittermeier, R.A., Mittermeier, C.G., da Fonseca, G.A.B. \& Kent, J. (2000) Biodiversity hotspots for conservation priorities. Nature, 403, 853-858

Nicoll, M.E. \& Langrand, O. (1989) Madagascar: Revue de la Conservation et des Aires Protégées. WWF, Gland, Switzerland.

O'Connor, S., Pidgeon, M. \& Randria, Z. (1986) Conservation program for the Andohahela Reserve, Madagascar. Primate Conservation, 7, 48-52.
Petter, J.-J., Albignac, R. \& Rumpler, Y. (1977) Faune de Madagascar 44: Mammiferes Lémuriens (Primates Prosimiens). ORSTROM/CNRS, Paris, France.

Plumptre, A.J. (2000) Monitoring mammal populations with line transect techniques in African forests. Journal of Applied Ecology, 37, 356-368.

Ramarokoto, S., Rakotosamimanana, B. \& Raharivololona, B.M. (1999) Situation actuelle des aires protégées à Madagascar: plan stratégique de l'ANGAP (Association Nationale pour la Gestion des Aires Protégées) de 1998 à 2000. Lemur News, 4, 5-7.

Rasoloarison, R.M., Goodman, S.M. \& Ganzhorn, J.U. (2000) Taxonomic revision of mouse lemurs (Microcebus) in the western portions of Madagascar. International Journal of Primatology, 21, 963-1019.

Rasoloarison, R.M. \& Rasolonandrasana, B.P.N. (1999) Les Lémuriens. In Inventaire Biologique de la Réserve Spéciale du Pic $d^{\prime} I v o h i b e$ et $d u$ Couloir Forestier qui la relie au Parc National d'Andringitra (eds S.M. Goodman \& B.P.N.

Rasolonandrasana), pp. 159-169. CIDST, Antananarivo, Madagascar.

Smith, R.J. \& Jungers, W.L. (1997) Body mass in comparative primatology. Journal of Human Evolution, 32, 423-559.

Sterling, E.J. \& Ramaroson, M.G. (1996) Rapid assessment of the primate fauna of the Eastern slopes of the Réserve Naturelle Intégrale d'Andringitra, Madagascar. In A Floral and Faunal Inventory of the Eastern Slopes of the Réserve Naturelle Intégrale d'Andringitra, Madagascar: With Reference to Elevational Variation (ed. S.M. Goodman), pp. 293-305. Fieldiana Zoology, n.s. 85. Field Museum of Natural History, Chicago, USA.

Struhsaker, T.R. (1981) Census methods for estimating densities. In Techniques for the Study of Primate Population Ecology (ed. Subcommittee on Conservation of Natural Populations), pp. 36-80. National Academy Press, Washington, DC, USA.

Sussman, R.W., Green, G.M., Porton, I., Andrianasolondraibe, O.L. \& Ratsirarson, J. (2003) A survey of the habitat of Lemur catta in south-western and southern Madagascar. Primate Conservation, 19, 32-57.

Tattersall, I. (1982) The Primates of Madagascar. Columbia University Press, New York, USA.

Turner, I.M. (1996) Species loss in fragments of tropical rain forest: a review of the evidence. Journal of Applied Ecology, 33, 200-209.

USGS (2003) United States Geological Survey. Http:/ /edc.usgs.gov/products/elevation/gtopo30.html [accessed 23 November 2004].

USGS (2004) United States Geological Survey. Http:/ /edc.usgs.gov/products/satellite/landsat7.html [accessed 23 November 2004].

White, F.J., Overdorff, D.J., Balko, E.A. \& Wright, P.C. (1995) Distribution of ruffed lemurs (Varecia variegata) in Ranomafana National Park, Madagascar. Folia Primatologica, 64, 124-131.

Whitesides, G.H., Oates, J.F., Green, S.M. \& Kluberdanz, R.P. (1988) Estimating primate densities from transects in a West African rain forest: a comparison of techniques. Journal of Animal Ecology, 57, 345-367.

Wyner, Y.M., Johnson, S.E., Stumpf, R.M. \& DeSalle, R. (2002) Genetic assessment of a white-collared $\mathrm{x}$ red-fronted lemur hybrid zone at Andringitra, Madagascar. American Journal of Primatology, 67, 51-66. 


\section{Biographical sketches}

Mitchell Irwin's research examines the effects of forest fragmentation on lemur ecology and behaviour. He has examined patterns of lemur extinctions in a network of forest fragments, and recently completed a year-long study of the feeding ecology of the diademed sifaka Propithecus diadema in forest fragments and continuous forest.

Steig Johnson's research interests include behavioural ecology, biogeography and speciation in strepsirhine primates, with a focus on the brown lemur Eulemur fulvus species complex. He has recently conducted fieldwork on disturbance effects on forest structure and animal populations as part of an interdisciplinary project modelling deforestation in south-eastern Madagascar.

Patricia Wright co-discovered the golden bamboo lemur Hapalemur aureus in 1986 at Ranomafana, and was instrumental in the creation of Ranomafana National Park in 1991. Recently she has spearheaded Centre ValBio, a research and training center at Ranomafana. She has received two medals of honor from the Malagasy government. 